\title{
ANABOLIC AND ANDROGENIC EFFECTS OF METHANDROSTENOLONE ("Nerobol") DURING SYSTEMATIC PHYSICAL ACTIVITY IN RATS
}

\author{
Professor V. ROGOZKIN \\ Research Institute of Physical Culture, Dynamo Avenue 2, 197047 LENINGRAD, USSR
}

Despite the limited number of published papers there is evidence of the efficiency of synthetic anabolic steroid hormones during training, particularly in sports events depending mainly upon the development of muscle size and strength. The considerable anabolic effect of these hormones has resulted in their wide-spread and uncontrolled application in sport.

A systematic 3-year-study of possible effects of methandrostenolone (nerobol), a much used synthetic anabolic steroid hormone, was conducted on animals in my laboratory in Leningrad Research Institute of Physical Culture by my co-workers Bazulko A., Tchaikovsky, V., Pliskin A., Pshendin A, and Silber M. Experimental data, presented here, reflect two main areas of research:

Firstly, investigation of the mechanisms of nerobol effect on transcription and translation processes in skeletal muscle under the conditions of non-repeated (strength) physical load.

Secondly, study of anabolic and androgenic effects of prolonged and reiterated application of nerobol combined with high physical loadings.

\section{Methods}

\section{(a) Anabolic effects}

Male albino rats weighing $160-200 \mathrm{gr}$ were used. Their diet included $18.5 \%$ of proteins.

$0.3 \mathrm{mg} / \mathrm{kg}$ of nerobol was dissolved in $1.0 \mathrm{ml}$ solution of $0.9 \% \mathrm{NaCl}$ and administered to animals 1 hour subsequent to physical activity.

Suspension of animals with $10 \%$ of their body weight balanced on a vertical rod for $6 \mathrm{~min}$. ( 3 times for $2 \mathrm{~min}$. with $1 \mathrm{~min}$ intervals for rest) was used as an experimental model of physical loading. The animals were then tested at rest, immediately after physical loading and at different periods of rest.

In skeletal muscle we evaluated both the aspartateamino-transferase and cytochrome-oxidase activity and incorporation of ${ }^{14} \mathrm{C}$-leucine into proteins of myofibrils and sarcoplasm. $\left({ }^{14} \mathrm{C}\right.$-leucine in a dose of $140 \mathrm{ci} / \mathrm{kg}$. of body weight was injected intraperitoneally $30 \mathrm{~min}$. prior to evaluation). The content of ${ }^{4} \mathrm{C}$-orotic acid in skeletal muscle RNA was then determined similarly in $30 \mathrm{~min}$. subsequent to intraperitoneal administration of the radioactive isotope in a dose of $500 \mathrm{ci} / \mathrm{kg}$. body weight.

Total ${ }^{14} \mathrm{C}$-RNA was isolated from muscles by the phenol-detergent method and analysis of radioactivity distribution in fractions was carried out after 6 hours centrifuging in linear sucrose density gradient. Nuclei isolated from skeletal muscles by differential centrifuging method in $2.2 \mathrm{M}$ sucrose were used to determine DNA-dependent RNA-Polymerase activity by method of Marchok and Wolf (1968).

\section{(b) Androgenic effects}

Androgenic effects were ascertained by changes in the animals' reproductive system, namely, by weight changes of ventral prostate and seminal vesicles.

\section{Results}

Nerobol administration immediately after exercise caused increased activity of both sarcoplasmic enzyme Aspartate-amino-transferase (AAT) and mitochrondrial enzyme - Cytochrome oxidase (Cy, OX). This increased level of activity is retained for 3 hours following the period of rest. (Table I).

\section{TABLE I}

\section{Activity of Enzymes in Rat Skeletal Muscle during Exercise}

\begin{tabular}{|c|c|c|c|c|}
\hline \multirow[t]{2}{*}{$\begin{array}{l}\text { Experiment } \\
\text { Conditions }\end{array}$} & \multicolumn{2}{|c|}{$\begin{array}{l}\text { AAT* } \\
\mu \text { moles of pyruvate/ } \\
\text { gr. tissue/min. }\end{array}$} & \multicolumn{2}{|c|}{$\begin{array}{l}\text { CyOx** } \\
\mu \text { moles of indopheno } \\
\text { blue/gr. tissue/min. }\end{array}$} \\
\hline & $\begin{array}{l}\text { Without } \\
\text { Hormone }\end{array}$ & $\begin{array}{l}\text { With } \\
\text { Nerobol }\end{array}$ & $\begin{array}{l}\text { Without } \\
\text { Hormone }\end{array}$ & $\begin{array}{l}\text { With } \\
\text { Nerobol }\end{array}$ \\
\hline 1. REST & $16,3 \pm 0,3$ & - & $564 \pm 17$ & - \\
\hline 2. EXERCISE & $15,3 \pm 0,3$ & - & $733 \pm 13$ & - \\
\hline \multicolumn{5}{|c|}{ 3. RECOVERY TIME } \\
\hline $\begin{array}{l}\text { after } 2 \text { hours } \\
\text { after } 3 \text { hours } \\
\text { after } 4 \text { hours }\end{array}$ & $\begin{array}{l}15,6 \pm 0,1 \\
16,0 \pm 0,1 \\
16,1 \pm 0,3\end{array}$ & $\begin{array}{l}21,4 \pm 0,5 \\
19,8 \pm 0,2 \\
18,0 \pm 0,2\end{array}$ & $\begin{array}{l}644 \pm 10 \\
630 \pm 8 \\
595 \pm 13\end{array}$ & $\begin{array}{l}756 \pm 17 \\
730 \pm 8 \\
655 \pm 14\end{array}$ \\
\hline
\end{tabular}


In the experiments with the administration of ${ }^{14} \mathrm{C}$-leucine it was established that the radioactivity of sarcoplasmic proteins in skeletal muscles at rest is twice as much as that of myofibrillar proteins (Table II).

\section{TABLE II}

\section{Incorporation of ${ }^{14} \mathrm{C}$-Leucine into Rat Skeletal Muscle Proteins during \\ Exercise (cpm $\times m$ protein $^{-1}$ )}

\section{Experiment Conditions}

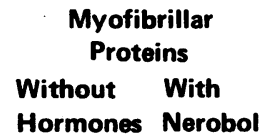

1. REST

2. EXERCISE

3. RECOVERY TIME

after 2 hours after 3 hours after 4 hours $247 \pm 13$ $296 \pm 16$ $226 \pm 14$ $236 \pm 19$

$286 \pm 19$ $292 \pm 11$ $239 \pm 13$

$211 \pm 16$

\section{Sarcoplasmic Proteins}

Without With Hormone Nerobol

$513 \pm 14$

$454 \pm 13$

$410 \pm 24 \quad 521 \pm 15$

$404 \pm 19 \quad 515 \pm 13$

$426 \pm 12 \quad 522 \pm 12$

$411 \pm 11 \quad 508 \pm 15$
The content of ${ }^{14} \mathrm{C}$-leucine in sarcoplasmic proteins after physical activity diminished while the synthesis of myofibrillar proteins remained practically unchanged. After nerobol administration, increased ${ }^{14} \mathrm{C}$-leucine incorporation into sarcoplasmic proteins is observed during 4 hours period of rest. No marked changes in the synthesis of myofibrillar proteins were found.

\section{TABLE III}

\section{Incorporation of ${ }^{14} \mathrm{C}$-Orotic acid into Rat} Skeletal Muscle RNA during Exercise

$\begin{array}{ll}\text { Experiment } & \text { RNA cpm } \times \mathrm{mg}^{-1} \\ \text { Conditions } & \text { Without Hormone }\end{array}$

With Nerobol

1. REST $308 \pm 25$

2. EXERCISE $204 \pm 17$

3. RECOVERY TIME

after 2 hours $\quad 394 \pm 16$

after 3 hours $\quad 403 \pm 12$

Physical activity causes a reduction in the rate of RNA synthesis in skeletal muscles (Table III). The incorporation of ${ }^{14} \mathrm{C}$-orotic acid into RNA gradually increased during recovery period following exercise. Rate of RNA synthesis in skeletal muscles of animals subjected to hormone treatment was significantly higher than that of control animals. For instance, RNA radio- $\omega$ activity of skeletal muscles in animals receiving nerobol was twice as high as that of control rats even in 5 hours ? rest period (Fig. 1).

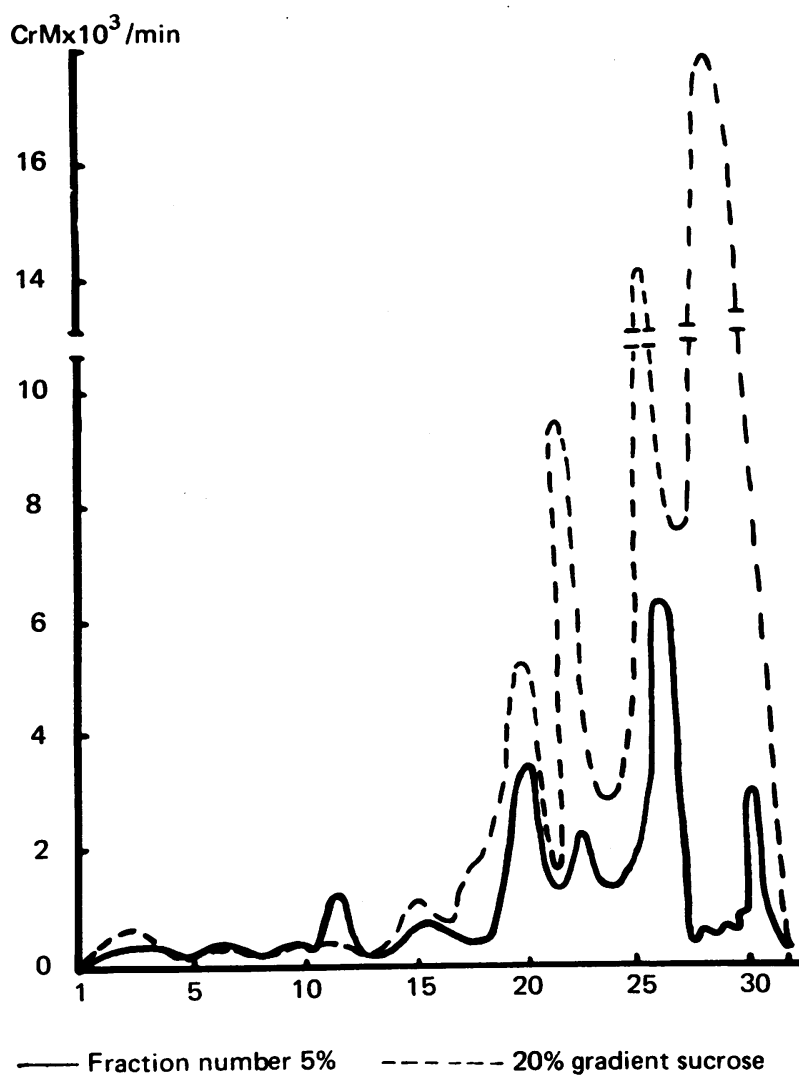

FIG. 1. DISTRIBUTION OF INCORPORATED RADIOACTIVITY IN DIFFERENT FRACTIONS OF RAT SKELETALO MUSCLE RNA DURING $5 \mathrm{hr}$ RECOVERY PERIOD AFTER EXERCISE.

WITHOUT HORMONE - WITH NEROBOL Centrifuging of this fraction of RNA in sucrose den- $N$ sity gradient permitted us to ascertain changes in radio- N activity distribution in RNA fractions. Increase in radio- 0 activity of the high-molecular RNA of skeletal muscles was found after hormone application.

The data received show that a single injection of ? nerobol after physical loading causes increase in enzyme 0 activity of skeletal muscles and elevated synthesis of $\overrightarrow{\mathbb{D}}$ sarcoplasmic proteins and high-molecular RNA.

Activity of DNA-dependent RNA-polymerase in nuclei of skeletal muscles was studied to ascertain nerobol 
effect on transcription process. Nerobol injection results in increase in polymerase enzyme activity. Actinomycin $D$ inhibits this reaction completely (Table IV).

\section{TABLE IV}

\section{Activity of Rat Skeletal Muscle Nuclear} RNA Polymerase after Nerobol Treatment

\begin{tabular}{|c|c|c|c|}
\hline \multirow{2}{*}{$\begin{array}{l}\text { Experiment } \\
\text { Conditions }\end{array}$} & \multicolumn{3}{|c|}{$\mu \mu$ moles ${ }^{3} H-U M P \times$ DNA -1} \\
\hline & $\begin{array}{l}\text { Complete } \\
\text { System }\end{array}$ & $-/ \mathrm{NH}_{4} / \mathbf{S O}_{4}$ & $\begin{array}{l}\text { Actino- } \\
\text { mycin D }\end{array}$ \\
\hline WITHOUT HORMONE & $724 \pm 34$ & $516 \pm 27$ & 0 \\
\hline WITH NEROBOL & $845 \pm 32$ & $836 \pm 36$ & 0 \\
\hline
\end{tabular}

Recent studies show that steroid hormone transportation into nuclei is provided by formation of specific complexes with receptor protein contained in cytoplasm. We hypothesized the existance of such a receptorprotein for nerobol as well. This assumption was confirmed by the results of model experiments with nuclei and cytoplasm (Table V). Addition of cytoplasmic extracts of skeletal muscles into RNA-Polymerase system provides a nerobol-stimulating effect. This effect is manifested both at rest and after physical activity.

\section{TABLE V}

\section{Effect of Nerobol on RNA Polymerase Activity in Rat Skeletal Muscle}

$\begin{array}{lll}\text { Experiment } & \text { Condition } & \begin{array}{c}\mu \mu \text { moles } \\ \text { mg DNA }\end{array} \\ \begin{array}{l}\text { NUCLEI } \\ \text { CYTOPLASM }\end{array} & \text { REST } & 1118 \pm 21 \\ \begin{array}{l}\text { NUCLEI } \\ \text { CYTOPLASM }\end{array} & \begin{array}{l}\text { REST } \\ \text { NEROBOL }(5 \mu \mathrm{g})\end{array} & 1343 \pm 16 \\ \begin{array}{l}\text { NUCLEI } \\ \text { CYTOPLASM }\end{array} & \begin{array}{l}\text { REST } \\ \text { EXERCISE }\end{array} & 885 \pm 23 \\ \begin{array}{l}\text { NUCLEI } \\ \text { CYTOPLASM }\end{array} & \begin{array}{l}\text { REST } \\ \text { EXERCISE } \\ \text { NEROBOL }(15 \mu \mathrm{g})\end{array} & 1116 \pm 22 \\ & \end{array}$

So we conclude that nerobol has a stimulating effect on the transcription process in skeletal muscles. This effect is realised due to both change of activity of the enzyme part of the transcription cemplex and modification of transcribed genome spectrum. The stimulating effect of nerobol on the activity of RNA polymerase of skeletal muscles is achieved after the formation of a hormone transportation complex with specific receptor present in cytoplasm. Intensification of transcription in skeletal muscle under influence of nerobol administration is probably one of the main reasons for the increase in synthesis of RNA and sarcoplasmic proteins - consequently resulting in expansion of functional potentialities of skeletal muscles.

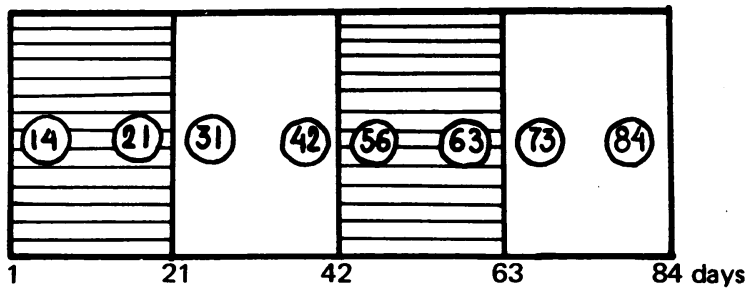

FIG. 2. EXPERIMENT - DESIGN OF RAT TRAINING WITH NEROBOL ADMINISTRATION

- TRAINING WITH NEROBOL TREATMENT

$$
\begin{aligned}
& \text { - TRAINING WITHOUT NEROBOL ADMINISTRATION } \\
& \text { - DAYS OF EXPERIMENTS }
\end{aligned}
$$

Solution of the second task required an additional 84-days experiment on animals. Experiment-design is shown in Fig. 2. Main stages of the procedure included injection of nerobol twice: during the first 21 days of training and then during the interval of 43rd - 64th days of training. Animals were tested 6 times every two weeks. This design made it possible to obtain more complete data on anabolic and androgenic effects of repeated application of nerobol during systematic physical training. Anabolic effect was estimated by measurement of animals' weight, RNA content and activity of AAT and CyOX enzymes in skeletal muscles. Changes in animals' weight is shown in Fig. 3. Their weight during the experiment increased from 190 to $\mathbf{3 1 0}$ gr. Animals subjected to hormone treatment while training gained weight more rapidly. These animals also had a higher

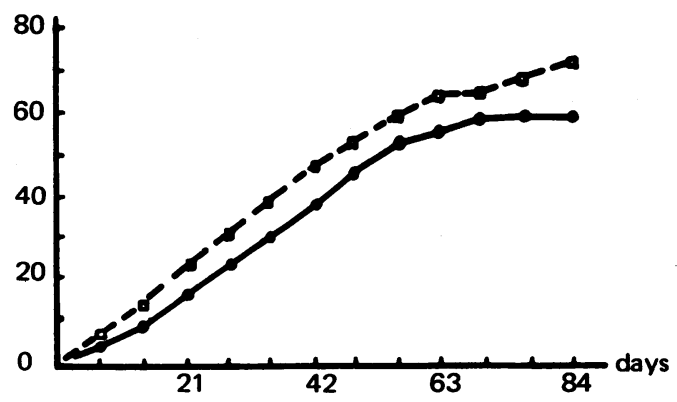

FIG. 3. EFFECT OF NEROBOL ADMINISTRATION ON BODY WEIGHT OF ANIMALS

$\longrightarrow$ - WITHOUT HORMONE $\rightarrow-$ WITH NEROBOL 
content of RNA in skeletal muscles after administration of the hormone (Fig 4). This figure also reflects phase changes of RNA level after the first and, particularly, after the second 3-weeks-long period of nerobol administration. It should be noted that RNA content in skeletal muscles decreased after discontinuance of nerobol administration, especially on the forty second and eighty fourth days of the experiment.

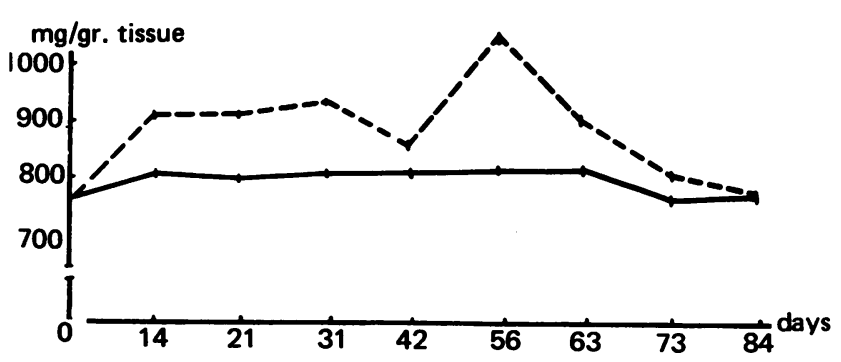

FIG. 4. EFFECT OF NEROBOL ON RNA CONTENT IN RAT SKELETAL MUSCLE

\section{— WITHOUT HORMONE $\quad$ - - WITH NEROBOL}

Nearly the same changes were observed in the enzymes activity. As could be seen from Fig. 5, the aspartate-amino-transferase (AAT) activity in skeletal muscles of animals receiving nerobol at these periods was higher than in control animals.

$\mu$ moles of pyruvate/

gr tissue/min

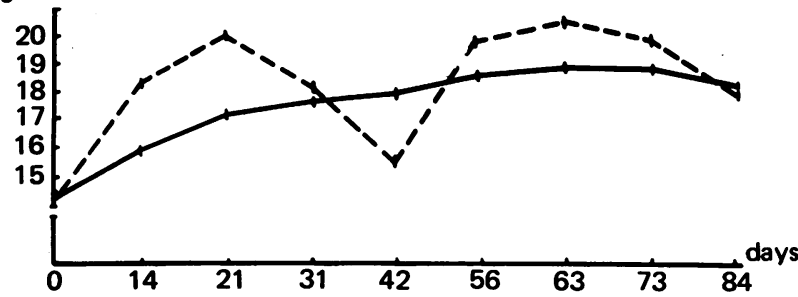

FIG. 5. EFFECT OF NEROBOL ON AAT ACTIVITY IN RAT SKELETAL MUSCLE

$$
\text { - WITHOUT HORMONE _ - - WITH NEROBOL }
$$

Results of investigation of cytochrome oxidase activity in skeletal muscles are shown in Fig. 6. Phase fluctuations of enzyme activity due to nerobol administration are also distinctly observed.

Therefore, the results of the study of nerobol anabolic effect on prolonged and repeated administration to trained animals showed varied effects on skeletal muscles metabolism. It was found out that RNA content in- $\mu$ moles of indophenol blue/

gr tissue/min.

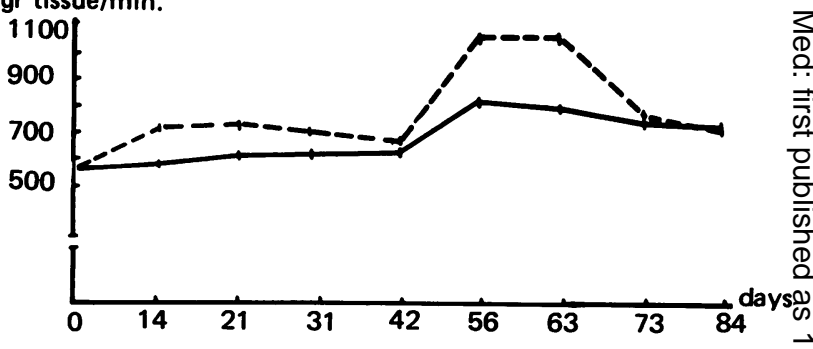

FIG. 6. EFFECT OF NEROBOL ON CYTOCHROME OXYDASE ACTIVITY IN RAT SKELETAL MUSCLE

- WITHOUT HORMONE $\quad$ - - WITH NEROBOL

creased and reactions of amino-acid transamination and $\delta$ oxidation were intensified. Intensification of synthetic $\mathrm{O}$ processes in general resulted in the increase in weight.

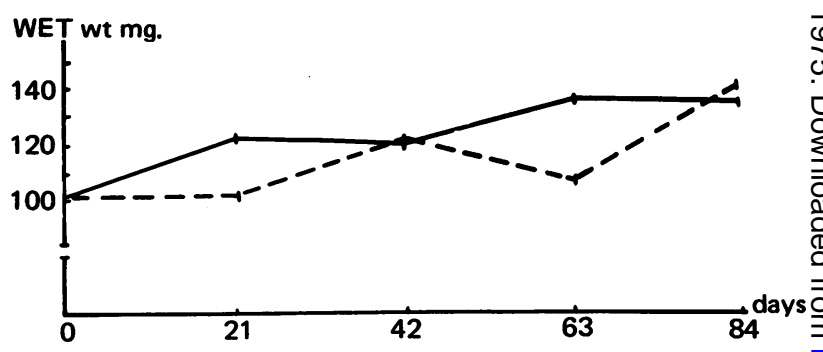

FIG. 7. EFFECT OF NEROBOL ON RAT PROSTATE WEIGHT

- WITHOUT HORMONE $\quad$ - - - WITH NEROBOL

Androgenic effect is usually estimated by changes in weight of ventral prostate and seminal vesicles. Measures of prostate weight are summarized in Fig. 7. It is clear 0 that nerobol administration suppresses the growth of this gland. Discontinuance of hormone administration 0 brings about a gradual restoration of prostate weight up to the level found in control animals.

As shown in Fig. 8, reduction in growth of seminal vesicles is observed during the period of nerobol administration whereas their recovery follows cessation of hormone treatment. Similar data were obtained regarding the weight of testicles.

Therefore, initial and repeated prolonged administration of nerobol to animals engaged in systematic physical activity causes androgenic effects on sexual glands manifesting itself in delay in growth of ventral prostate seminal vesicles and testicles. 


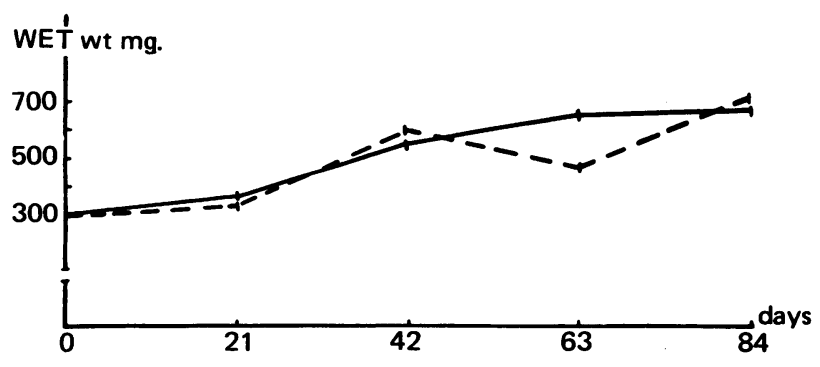

FIG. 8. EFFECT OF NEROBOL ON WEIGHT OF RAT PROSTATE VESICLES

- WITHOUT HORMONE - - - WITH NEROBOL

\section{Conclusions}

On the basis of the experimental data obtained the following conclusions can be made:

Firstly, nerobol has a widespread effect on metabolism in animals. This hormone takes part in regulation of protein synthesis in skeletal muscles at genome level. Intensification of RNA-synthesis at chromatin level serves as a trigger in realization of nerobol anabolic effect in skeletal muscles of animals engaged in physical activity. Subsequently, the protein synthesis becomes activated which causes, first of all, the intensification of synthesis of sarcoplasmic enzyme proteins.

Secondly, and this is the most important. Nerobol inhibits the function of the sexual glands. The androgenic effect of nerobol is shown by weight reduction of the ventral prostate, testicles and seminal vesicles, as well as in the decrease in volume of secretion in the seminal vesicles.

The androgenic effect of nerobol makes its use for intensification of anabolic processes in the healthy organism during training undesirable, especially considering the practical difficulties in measurement of androgenic effect at present.

Naturally, such a comment may give rise to objections and probably great efforts will be needed to realize our proposal in sport. Therefore, I'd like to conclude my paper with the following English proverb:

"Where there is a will, there is a way". 